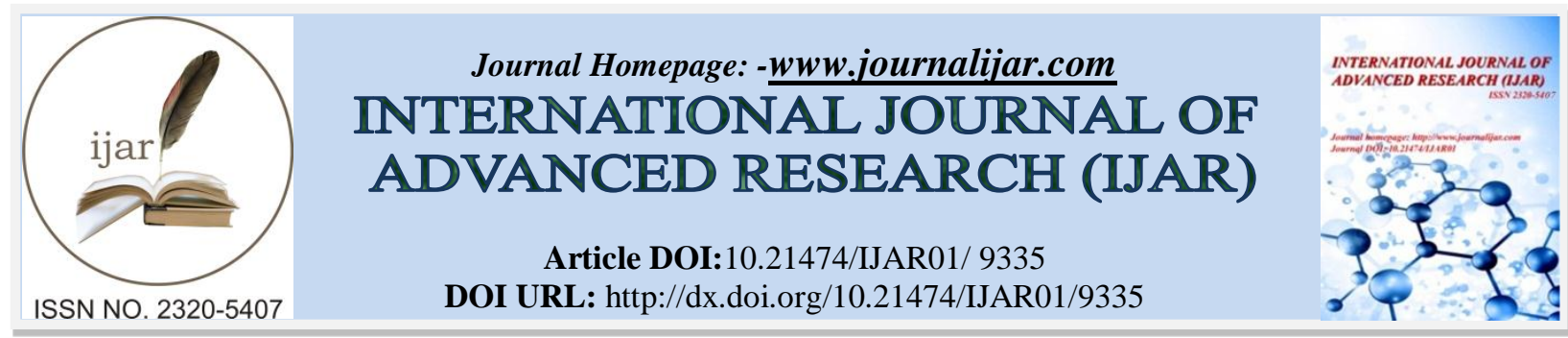

RESEARCH ARTICLE

\title{
ROLE OF A TEACHER IN MAN MAKING MISSION.
}

Dr. Pradnya s. Yenkar.

Associate Professor, Department of English, Vidyabharati Mahavidyalaya, Amravati (MS)-444602.

\section{Manuscript Info}

Manuscript History

Received: 04 May 2019

Final Accepted: 06 June 2019

Published: July 2019

Key words:-

Innovative Education, Inculcating

Values among Youth, Reforms in

Education, Imparting Value Education.

\begin{abstract}
The Popular concept of modern education, particularly higher education, has adversely changed with the main objective of passing the university examinations with good marks and giving a few vocational skills to fit into the job. Higher education in science and technology, which, majority of science students opt tries to equip them for materialistic development, which is mistaken for 'progress'. The engineers, doctors, scientists, economists and men of commerce change very much in the name of civilisation and they advance materialistically. Change and materialistic development do not signify human progress and the progress of the society. The teaching community today faces an endless and challenging task of imparting value education and value based education. The present paper discusses the need of inculcating values among students and role of teacher in building the next generation. The issues and problems of young India and their reflections on the educational development with respect to goals of education, curriculum, innovations and the importance of teacher's role are also discussed in brief.
\end{abstract}

Copy Right, IJAR, 2019,. All rights reserved.

\section{Introduction:-}

India entered the twenty-first century with the burden of one crore of people. The rate of mortality has declined. The span of life is increased. The pressure of old people and the idle population is also increased. The whole demographic profile of the country gets transformed. The problems of housing, habitats, transport, health, food, unemployment, education and country and town planning became multi-dimensional. The control of population is still remained one of the gravest problems in the twenty-first century. Now the population studies and population education have to share greater responsibility in this context. With all attempts to transform the Indian society into modern and developed nation, India entered the twenty first century with her tribal, rural, urban and metropolitan social divisions and her fourfold levels of development: primitive, agricultural, industrial and post-industrial.

\section{Transmission of Culture:}

It is the culture that makes man 'human'1. At the societal level the culture provides solidarity and cohesion for the society by binding its members together. It is culture, which is responsible for maintaining the continuity of a society in spite of periodic changes in membership due to birth, death and immigration. Each generation of a society passes on its social heritage and cultural tradition to the next generation which is known as transmission of culture.

Corresponding Author:-Pradnya s. Yenkar. Address:-Associate Professor, Department of English, Vidyabharati Mahavidyalaya, Amravati (MS)444602. 


\section{Education Imparted in Gurukulas:}

Academic institutions in India were Gurukulas for centuries where the Gurus gave the students a multidimensional man-making education. This education co-ordinated the head, heart and hand which took care of the intellectual and emotional growth of the students and the development of their skills. The gurus believed that education was a process in Gurukulas where the students developed into the respectable citizens. They taught the students values, which guided them to healthy and harmonious social life; the gurus believed that human values were what the students live by and what they would die for. The gurus were convinced that providing the students with the knowledge and skills that would enable them to realize their professional aspirations is only a part of their education; the more important part was making them young citizens of values, culture and patriotism. Culture was the watch word in ancient Indian life. The gurus prepared the students to face the challenges of career and life by inculcating in them values of the culture and developing in them a positive attitude; values and the right attitude helped their own progress and the progress of their society.

\section{Art of Living with Values:}

Times are hard for student community of our country. Today the colleges and universities are expected to produce graduates with unflinching integrity, a stiff spine, a kind but firm heart, a heavy measure of devotion, competence and confidence. In short' gentleman of character' but instead the present day-youth is surrounded by mobiles \& electronic gadgets, whatsapp \& Facebook, rum and rock, drugs and daggers. The students encounter the vast and confusing market place of ideas, theories and lifestyles that they meet in and outside the classroom. The young voice ideas and pursue goals that they feel will please their parents, but which they have not truly chosen for themselves. Value clarification is a helpful tool in giving them singleness of purpose and the ability to discard what is inappropriate and destructive to them. They need to constantly exercise judgement and make decisions and to develop the capacity to live with doubts and yet be able to function which is another facet of collegiate experience. Therefore moral development depends not on what subject is taught but on how it is communicated.

Values are standard and patterns of choice that guide persons and groups towards satisfaction, fulfilment and meaning. Values serve as the authorities in the name of which choices are made and action is taken. Many abstract nouns that are associated with this come readily to our mind: honesty, integrity, courage, care, freedom, order, justice, pleasure, compassion, status, loyalty, security, friendship, trust, success, love, efficiency, peace, power, respect, tolerance, etc. Including ideas such as in a pragmatic curriculum provides students with an effective and rigorous preparation for dealing adequately with critical human choices and problems, especially those that have moral consequences.

\section{Importance of Value Judgement in Learning:}

Today the curriculum needs to insist on educating the young students in the art of living with values. If learning remains detached from value judgements, scholarship runs the risk of degenerating into indifference. Value judgements actually enhance the accuracy of learning. Teachers therefore should be aware of the important role they are called upon to play as professionals and citizens, as agents of development and change. They must make an effort to light a candle instead of cursing the darkness and sow the seeds of value education with a fond hope that they would diffuse their own fragrance towards the creation of a just and new society as they sprout and blossom. W.G. Cole in his article 'The restless quest of Modern Man' says 'value judgements are inescapable demands of life for however unconscious and undeliberate the choice, everyman finds himself inextricably entangled in a web of values on which his very life depends. ${ }^{2}$

\section{Need of Value Education:}

In the article 'Teaching values in college' Richard L. Morrill says that 'education has become a form of preprofessional training without disciplinary perspectives to bind the norms of intellect to the demands of conscience ${ }^{3}$. He points out that the students these days separate facts from values and they are a split between reason and emotion, knowledge and affection. Though educators have made significant contributions by using different classroom situations to inculcate values our students continue to face many problems. This is an age, when the past is irrelevant, the present uncertain and the future confused and fearful. Traditional values have never been so radically rejected and rules so violently violated as they are today. The young find the gap between the teachers' professed and lived values. They search for their identity, for a purpose in life and for a meaningful human destiny, individually and historically. However this search is difficult as their vision is blurred, due to various pressures from without and within themselves and hence the disequilibrium. 
Educational philosophy of Gandhiji says that value education is an essential part of one's endeavour of identification by means of self-enquiry, self-analysis and self-evaluation. Such type of education for values therefore necessitates an approach that harmonises the essential components contributing to the growth and development of personality ${ }^{4}$. Gandhiji repeatedly warns against the dangers of passivity and dependence on knowledge, which merely turn out to serve like an ornament and dominates over our sense and feeling, creativity and critical thinking.

\section{Role of a Teacher in Restructuring Values:}

Teacher has to play the key role in making the value educated young India. The tertiary education needs to be differently specialized. Humanities, social sciences, law and commerce should no remain exclusive departments; rather these should be disciplines of high prestige attached with institutes of Science and technology as well as centres of development and cultural dissemination. The knowledge regarding History of India's freedom movement, constitutional obligation, contents essential to nurture national identity, India's common cultural heritage, egalitarianism, democracy and secularism, equality of sexes, protection of the environment, removal of social barrier, observance of the small family norm, and the inculcation of scientific temper needs to be added in the regular curricula.

Swami Vivekananda says 'Education for values should be education for man-making and character building. Values like cooperation, tolerance and neighbourliness, austerity and so on should be exercised in right earnest in the continual course of education'

A deep awareness and respect for the principles enshrined in the constitution and a willingness to further the rule of law with commitment to national identity, integration, non-violence, secularism and socialism become necessary to instil in the youth. It is necessary to create a strong awareness of Indian cultural heritage with a commitment to their preservation as well as enrichment of their environment and ecology. The qualities of disciplines, self-reliance, justice and fair play, sporting spirit, concern for public welfare and scientific temper to combat superstition, obscurantism, and such social evils need to be developed among the youth. Maximum access to education for personality development as well as vocational training needs to be provided. The Indian youth must be made aware of international issues and involved in promoting peace and understanding a just economic order.

\section{Conclusion:-}

Against many destructive non-values such as egoism, arrogance, domination, corruption and money-power in the society today, there is still the longing for ushering in and striving for a new society based on justice, equality and common fellowship. As teachers have always claimed a special capacity to influence conduct and to shape moral character, the society expects them to develop not only knowledge but also ethical values among students thus creating an environment that would fraternity amongst mankind. Value education directly or indirectly, attempts to help the students answer some of the basic questions they ask themselves, through positive approach and attitudinal changes. Value clarification process will enable them to live by conviction rather than convenience. Knowledge of values, attitudes, needs and their ideals and actual selves, will lead them to an awareness of self and the others, thus making their interactions and responses more fruitful. Once the students have their values clarified, they are able to perform better, academically and socially. In short, Values provides human beings with a very possibility of existence as human beings.

\section{References/Work Cited:-}

1. Jayaraman N,(1990), Sociology of Education in India, Jaipur, Rawat Publications.

2. Cooper David E, Ed.(1986) Education, Values and Mind: Essays for R S Peters, London,Routledge and Kegan Paul

3. Morill Richard L. (1980) Teaching Values in College, San Francisco, Jossey- Bass Publishers.

4. Chakrabarti Mohit (1997) Value Education: Changing Perspectives, New Delhi: Krishna Publications, Distributors

5. Purushothaman and antony Stella (1995), New Delhi Educational Innovations. 